\title{
STATUS PENYELENGGARAAN PERADILAN HAM DI INDONESIA BERBASIS HUKUM INTERNASIONAL
}

\author{
Nurul Huda \\ Fakultas Hukum Universitas Pekalongan \\ email:NHD_AR@yahoo.com
}

\begin{abstract}
The era of respect for Human Rights (HAM) in Indonesia was marked by the issuance of regulatory/legal instruments both in the state constitutional amendment after amendment and legislation in the form of legislation include Act No. 26 of 2000 on Human Rights Court which is substantially oriented the Rome Statute. Apparently, Act No. 26 of 2000 is a product of the criminal policy "compromise models" because on one hand there is a setting which adopted the Rome Statute and on the other hand found a variety of different conditions deviate and with the statute. Though International legal instruments is one of the sources oflaw are important to the national legal system.
\end{abstract}

Keywords: Court of Human Rights, International Instruments, Rome Statute

\begin{abstract}
Abstrak
Era penghormatan terhadap Hak Asasi Manusia (HAM) di Indonesia ditandai oleh disyahkannya regulasi / instrument hukum baik di dalam amandemen konstitusi negara maupun perundangan dalam bentuk undangundang diantaranya adalah Undang-Undang nomor: 26 tahun 2000 tentang Pengadilan Hak Asasi Manusia yang substansinya berkiblat pada Statuta Roma. Nampaknya UU nomor 26 tahun 2000 merupakan produk kebijakan criminal "model kompromi" sebab di satu sisi terdapat pengaturan yang mengadopsi pada Statuta Roma dan pada sisi lain ditemukan berbagai ketentuan yang menyimpang dan berbeda dengan statute tersebut. Padahal instrument hukum internasional merupakan salah satu sumber hukum yang penting bagi system hukum nasional.
\end{abstract}

Kata kunci: Peradilan HAM, Instrumen Internasional, Statuta Roma

\section{A. Pendahuluan}

Proses pembentukan hukum pidana nasional yang sekarang terus berlangsung, terutama dalam bentuk legislasi undangundang di luar KUHP maupun Rancangan KUHP, tidak bisa dilepaskan dari alasanalasan yang bersifat ideologis, politis dan sosiologis. ${ }^{1}$ Disamping alasan tersebut, berdasar kajian yang komprehensif, terdapat pula alasan-alasan lain yang juga cukup penting yaitu alasan adaptif yaitu bahwa hukum pidana nasional masa datang harus dapat menyesuaikan diri dengan perkembangan-perkembangan baru di dunia internasional yang sudah disepakati oleh masyarakat internasional. ${ }^{2}$

Kecenderungan atau issue internasional yang sangat menonjol pada dekade terakhir ini adalah masalah hak asasi manusia (HAM).
Salah satunya adalah Statute International Criminal Court Roma (ICC) atau Statuta Roma, yang disyahkan pada tanggal 17 Juli 1998 dan secara formal telah resmi beroperasi sejak bulan Juli 2002, setelah diratifikasi oleh minimal 60 negara. ${ }^{3}$

Indonesia sebagai bagian dari komunitas negara-negara di dunia, sekalipun telah ikut menyetujui statuta ini, sampai sekarang belum melakukan ratifikasi dalam hukum nasionalnya, sekalipun sekarang ini telah memiliki Undang-Undang nomor 26 tahun 2000 tentang Pengadilan Hak Asasi Manusia. Itu artinya, belum ada harmonisasi instrumen hukum internasional pada sistem hukum nasionalnya terkait dengan ICC, walaupun diakui di dalam UU tersebut bahwa muatan materinya sebagian berkiblat pada Statuta Roma.

\footnotetext{
1. Muladi, Proyeksi Hukum Pidana Materiil Indonesia di Masa Datang, Pidato Pengukuhan Penerimaan Jabatan Guru Besar Ilmu Hukum Pidana di Fakultas Hukum UNDIP Semarang; 24 Pebruari 1990, hlm. 3.

2. Loc.cit.

3. Eddy Djunaedi Karnasudirdja, 2003, Dari Pengadilan Internasional Nuremberg ke Pengadilan Hak Asasi Manusia Indonesia,
} 
Hal tersebut bisa dilihat dari penjelasan pasal 7 UU nomor 26 tahun 2000 yang menyebutkan bahwa kejahatan genosida dan kejahatan terhadap kemanusiaan dalam ketentuan ini sesuai dengan "Rome Statute of The International Criminal Court (pasal 6 dan pasal 7).

Sementara itu bila melihat penjelasan umumnya, kelahiran UU ini didasari dan memiliki landasan hukum dalam konstitusi negara, deklarasi universal tentang HAM, Ketetapan MPR RI nomor: XVII/MPR/1998 tentang Hak Asasi Manusia dan UndangUndang nomor: 39 tahun 1999 tentang Hak Asasi Manusia, yang harus dilaksanakan dengan penuh rasa tanggung jawab sesuai dengan falsafah negara Pancasila.

Nampaknya, UU nomor 26 tahun 2000 merupakan produk kebijakan kriminal "model kompromi" sebab tidak semua ketentuan dalam UU tersebut persis sama dengan ketentuan yang diatur oleh Statuta Roma. Persoalan ini yang kemudian memunculkan banyak kritik terutama dari para aktivis dan penggiat HAM seperti yang dilakukan oleh Amnesty Internasional dalam laporannya pada bulan Pebruari 2001, antara lain memunculkan kekhawatiran terdapatnya pasal-pasal dalam UU Pengadilan HAM yang tidak cocok atau tidak sesuai dengan definisi menurut hukum internasional.

Ujian terhadap pelaksanaan UU Pengadilan HAM di Indonesia masih terbentang luas terkait dengan berbagai kasus pelanggaran HAM berat. Sebagaimana ditulis oleh Inggrid Silitonga, terdapat beberapa kasus pelanggaran HAM berat, diantaranya pembunuhan massal 1965-1967, pembunuhan dan penghilangan paksa dalam operasi militer terbatas di Aceh dan Irian Jaya (1976-1983), pembunuhan misterius (19831986), penangkapan, penyiksaan, dan pembunuhan para aktifis politik Islam pasca penerapan asas tunggal Pancasila (19851988), pembantaian di Talangsari - Lampung (Februari 1989), pembantaian petani Nipah Madura (1993) dan Kerusuhan Mei 1998. ${ }^{4}$

Sesuai dengan ketentuan umumnya, dinyatakan bahwa undang-undang nomor 26 tahun 2000 tentang Pengadilan HAM yang diundangkan pada masa pemerintahan
Presiden Abdurrahman Wahid pada tanggal 23 November tahun 2000, merupakan pengadilan khusus terhadap pelanggaran hak asasi manusia yang berat, yang kedudukannya berada di lingkungan peradilan umum. Menurut UU ini, pelanggaran hak asasi manusia yang berat meliputi kejahatan genosida dan kejahatan terhadap kemanusiaan (pasal 7).

Dengan demikian, kelahiran UU Pengadilan HAM di Indonesia, telah melahirkan kriminalisasi baru dalam bentuk pelanggaran HAM berat dalam konteks penyelenggaran sistem peradilan pidana, baik pada tataran materiil maupun formilnya, bersanding dengan ketentuan hukum pidana materiil dan pidana formil yang sudah ada sebelumnya.

Mengingat bahwa pasca lahirnya UU Pengadilan HAM ini memiliki konsekuensi dan dimensi persoalan-persoalan baru yang memiliki cakupan luas, bukan hanya persoalan yuridis, tetapi juga sosial dan politik, maka pengertian dan pemahaman mengenai penyelenggaraan peradilan HAM di Indonesia menjadi sesuatu yang cukup penting untuk diketahui, setidaknya mengenai 2 (dua) masalah yang akan menjadi kajian dalam tulisan ini, meliputi: pertama, apa yang menjadi ruang lingkup peradilan HAM berdasarkan Undang-Undang nomor: 26 tahun 2000 tentang Pengadilan HAM dan kedua, bagaimana keterkaitan / kesesuaian UU Pengadilan HAM dengan instrumen hukum internasional?

\section{B. Pembahasan \\ 1. Ruang Lingkup Peradilan HAM}

Kelahiran UU nomor 26 tahun 2000 tentang Pengadilan HAM (UUPH) secara politis dilatarbelakangi oleh kasus Timor Timur terutama pasca jajak pendapat pada kisaran akhir tahun 1999, yang berdampak terjadinya berbagai kasus kekerasan di wilayah tersebut.

Menurut berbagai pengamat internasional, sebagaimana dikutip Eddy Djunaidi, kasus Timor Timur merupakan sedikit kasus dalam konteks hukum internasional yang mendapatkan perhatian cukup serius oleh PBB (bahkan sejak tahun

4. www.eslam.or.id diakses" Inggrid Silitonga, Pengakan Keadilan atas Pelanggaran Berat HAM menurut UU nomor 26 tahun 2000 ,

Skenario Indonesia versus Standard Internasional, diakses dari pada tanggl 10 Januari 2015. 
1975) yang membutuhkan begitu banyak mekanisme kerja yang dilakukan oleh berbagai badan PBB. ${ }^{5}$

Sebagaimana diketahui, desakan internasional yang demikian kuat dan untuk melindungi kepentingan nasional yang lebih besar, pada akhirnya mendorong terbentuknya UUPH yang merupakan pengganti Perpu yang sama yang sudah ada sebelumnya. Operasionalisasi UU ini pertama kali diterapkan untuk mengadili pelanggaran HAM berat yang terjadi di Timor Timur pasca jajak pendapat dan kasus Tanjung Priok yang terjadi pada tahun 1984.

Sesuai dengan konsiderannya, disebutkan bahwa pembentukan UU Pengadilan HAM adalah dalam rangka "ikut serta memelihara perdamaian dunia dan menjamin pelaksanaan hak asasi manusia serta memberi perlindungan, kepastian, keadilan, dan perasaan aman kepada perorangan ataupun masyarakat". Penegasan mengenai hal tersebut juga dicantumkan dalam penjelasan umumnya.

Menurut UUPH, yang dikategorikan sebagai perbuatan pelanggaran HAM berat adalah kejahatan genosida dan kejahatan terhadap kemanusiaan. Elemen atau unsur kejahatan genosida dijelaskan oleh pasal 8, sedangkan kejahatan terhadap kemanusiaan dijelaskan dalam pasal 9. Secara substantif, perumusan tindak pidana pelanggaran HAM berat yang tercantum pada pasal-pasal tersebut mendapatkan banyak kritik, antara lain unsur-unsur deliknya tidak mendapatkan penjelasan yang memadai, sehingga akan membuka ruang interpretasi, yang kalau tidak dilandasi penguasaan literatur yang memadai akan berakibat fatal. ${ }^{6}$

Senada dengan pendapat tersebut, Harifin A. Tumpa juga melihat adanya kelemahan yang mendasar terkait dengan elemen tindak pidananya, yang berpotensi menimbulkan kesulitan dalam proses pembuktian.?

D i l i h a t d a r i a s e k pertanggungjawabannya, UU ini hanya mengenal manusia individu sebagai subyek hukumnya sebagaimana yang selama ini dianut oleh KUHP. Akan tetapi, dimungkinkan adanya sistem pertanggungjawaban pengganti (vicarious liability) dalam bentuk pertanggungjawaban komando sebagaimana dapat dilihat dalam pasal 42. Pasal 42 ayat (1) menyebut komandan militer atau seseorang yang secara efektif bertindak sebagai komandan militer dapat dipertanggungjawabkan terhadap tindak pidana yang berada di dalam yurisdiksi pengadilan HAM, yang dilakukan oleh pasukan yang berada di bawah komando dan pengendaliannya yang efektif, atau di bawah kekuasaan dan pengendaliannya yang efektif dan tindak pidana tersebut merupakan akibat dari tidak dilakukan pengendalian pasukan secara patut.

Hampir sama dengan ketentuan tersebut dapat juga dilihat pada ketentuan pasal 42 ayat (2), dimana seorang atasan, baik polisi maupun sipil, bertanggungjawab secara pidana terhadap pelanggaran HAM yang berat yang dilakukan bawahannya yang berada di bawah kekuasaan dan pengendaliannya yang efektif, karena atasan tersebut tidak melakukan pengendalian terhadap bawahannya secara patut dan benar.

Mengenai ancaman pidana terhadap pelaku kejahatan pelanggaran HAM berat, sebagaimana diatur dalam ketentuan pidana dari pasal 36 sampai pasal 41, terlihat adanya perbedaan dengan sistem yang selama ini dikenal, utamanya bila dibandingkan dengan ketentuan yang selama ini dianut oleh KUHP, sebab terdapat ketentuan ancaman minimum pidana khusus yaitu 10 (sepuluh) tahun penjara (pasal 36, 37 dan pasal 40), dan 5 (lima) tahun penjara (pasal 38 dan pasal 39). Perbedaan juga dapat ditemukan pada ancaman pidana maksimum yang dapat dijatuhkan yang mencapai 25 (duapuluhlima) tahun penjara (pasal 36 dan 37), yang sudah tentu berbeda dengan ancaman maksimum pidana dalam KUHP yaitu 20 (duapuluh) tahun. Hanya saja, melihat persamaannya dengan KUHP, UU ini masih mempertahankan ancaman pidana mati

5. Eddy Djunaedi Karnasudirdja, Op.cit, hlm. 77

6. Ifdhal Kasim, UU Pengadilan HAM Sebuah Tinjauan, Jakarta, ELSAM, dalam www.eslam.or.id, diakses pada tanggal 10 Januari 2015,.

7. Harifin A. Tumpa, Yurisdiksi Peradilan Pidana Indonesia Terhadap Pelanggaran HAM Berat dalam Rangka Penerapan Statuta Roma di Indonesia, Jakarta, majalah Varia Peradilan edisi tahun ke-XXI no. 252 November 2006 
(pasal 36 dan 37).

Ancaman pidana pada percobaan, permufakatan jahat dan pembantuan delik pelanggaran HAM berat adalah sama dengan delik selesai atau delik sempurna. Hal ini dinyatakan di dalam ketentuan pasal $41 .{ }^{8}$

Dalam pelaksanaan pemeriksaan perkara pelanggaran HAM berat, dikenal 2 (dua) macam lembaga peradilan, yaitu pengadilan HAM yang bersifat permanen dan pengadilan HAM Ad-hoc. Kewenangan yang dimiliki oleh pengadilan HAM yang bersifat permanen adalah memeriksa dan mengadili setiap perkara pelanggaran HAM berat yang terjadi setelah pemberlakuan / pengesahan UU Pengadilan HAM yakni sesudah tanggal 23 November 2000, sedangkan pengadilan HAM Ad-hoc memiliki kewenangan untuk memeriksa dan mengadili kasus pelanggaran HAM berat sebelum dikriminalisasikannya pelanggaran HAM atau sebelum adanya UUPH. Penegakan hukum pidana yang menjadi kewenangan pengadilan HAM yang bersifat ad-hoc ini merupakan suatu penyimpangan keberlakuan asas legalitas yang menganut prinsip retroaktif. ${ }^{9}$

Sebagai konsekuensinya, terdapat perbedaan dalam proses-proses yang harus dilalui sebelum suatu perkara pelanggaran HAM berat masuk ke pengadilan HAM.

Pada kasus pelanggaran HAM berat yang terjadi setelah pemberlakuan UU Pengadilan HAM, dimulai dari kegiatan penyelidikan yang dilakukan oleh Komnas HAM. Lembaga ini dalam melaksanakan penyelidikan dapat membentuk tim ad-hoc yang terdiri dari komnas HAM dan unsur masyarakat. Tim yang berfungsi melakukan penyelidikan ini diberikan kewenangankewenangan tertentu seperti menyelidiki dan memeriksa, menerima laporan atau pengaduan, meninjau dan mengumpulkan keterangan di tempat kejadian perkara dan pada akhirnya menyerahkan hasil penyelidikan kepada Jaksa Agung sebagai penyidik.

Pemeriksaan perkara oleh pengadilan
HAM (permanen) dilakukan dengan 5 orang hakim dengan komposisi 2 hakim pengadilan HAM dan 3 orang hakim HAM ad-hoc.

Berdasarkan ketentuan mengenai proses-proses yang harus dilalui sebelum perkaranya diperiksa oleh pengadilan HAM, menunjukkan bahwa undang-undang memberikan ketentuan adanya kewenangan penyelidikan oleh Komnas HAM, bukan oleh kepolisian dan adanya penegasan bahwa kewenangan penyidikan ada pada Jaksa Agung. ${ }^{10}$

Secara prinsip, proses yang membedakan pada penyelesaian perkara melalui pengadilan HAM ad-hoc, nampak pada ketentuan pasal 43 ayat (2) yang menyatakan bahwa Pengadilan HAM ad-hoc dibentuk atas usul DPR RI berdasarkan peristiwa tertentu dengan Keputusan Presiden.

Berdasar ketentuan pasal tersebut, bekerjanya sistem peradilan pidana dalam pemeriksaan perkara pelanggaran HAM berat yang terjadi sebelum pengundangan UU Pengadilan HAM memiliki karakteristik khusus, yaitu ditetapkan dalam keputusan presiden (keppres) berdasarkan usul Dewan Perwakilan Rakyat (DPR) RI, hal ini berarti ada intervensi lembaga legislatif dan eksekutif dalam bekerjanya penegakan hukum pidana. ${ }^{11}$

Persoalan yang menyertai ketentuan tersebut adalah bahwa UU tidak memberikan pengaturan yang lebih terperinci mengenai mekanisme atau proses hingga ditetapkannya keppres pembentukan pengadilan HAM adhoc. Dengan mengutip pendapat yang pernah disampaikan oleh Yusril Ihza Mahendra (Menkumham pada masa pemerintahan Abdurrahman Wahid), secara teknis mekanisme pembentukan pengadilan HAM ad-hoc adalah sebagai berikut: ${ }^{12}$

a. Berdasar ketentuan pasal 18 ayat (1), Komnas HAM melakukan penyelidikan terhadap pelanggaran HAM yang berat, termasuk yang terjadi sebelum ditetapkannya UU Pengadilan HAM;

b. Hasil penyelidikan Komnas HAM

8. Pasal 53 dan 55 KUHP. Aturan dalam pasal 41 UU Pengadilan HAM sama seperti yang dianut oleh UU Tipikor.

9. Boleh tidaknya suatu ketentuan dalam hukum pidana berlaku secara surut sangat tergantung dari pengaturan masalah tersebut dalam konstitusi. Konstitusi UUD 1945 pasca amandemen nampaknya melarang pemberlakuan secara surat suatu ketentuan undang-undang.

10. I Gede Widhiana Suarda, Hukum Pidana Internasional Sebuah Pengantar, Bandung, Citra Aditya Bhakti, 2012 , hlm. 235.

11. I Gede Widhiana Suarda, ibid, hlm. 236.

12. Loc.cit 
diserahkan ke Jaksa Agung untuk kemudian dilakukan penyidikan;

c. Jika penyidik menemukan cukup bukti bahwa telah terjadi pelanggaran HAM yang berat yang terjadi sebelum diundangkannya UU Pengadilan HAM, maka hasil penyidikan tersebut (melalui Presiden) oleh Jaksa Agung disampaikan kepada DPR sekaligus dengan permintaan agar DPR mengajukan usul kepada Presiden untuk membentuk Pengadilan HAM ad-hoc;

d. Jika DPR setuju atau sependapat dengan permintaan Jaksa Agung maka DPR akan mengajukan usul kepada presiden agar ditetapkan keppres pembentukan sebuah pengadilan HAM ad-hoc.

Melalui mekanisme seperti disebut di atas, pembentukan pengadilan HAM ad-hoc untuk kasus Timor Timur pasca jajak pendapat dan kasus Tanjung Priok ditetapkan oleh Presiden.

Dari uraian tentang bekerjanya sistem peradilan pidana pada Pengadilan HAM (permanen) dan Pengadilan HAM Ad-hoc, terdapat persamaan dan perbedaan diantara keduanya. Persamaannya terletak pada kewenangan yang dimiliki yaitu untuk memeriksa dan memutus perkara pelanggaran HAM berat yaitu kejahatan genosida dan kejahatan terhadap kemanusiaan, sedangkan perbedaannya terletak pada prinsip-prinsip atau asas-asas hukumnya, yurisdiksi mengadili, mekanisme pembentukannya dan masa berlakunya.

Selain pendekatan hukum pidana (penal), UU Pengadilan HAM ternyata juga mengakomodir model penyelesaian dengan pendekatan non hukum pidana (non-penal), sebagaimana dapat dilihat pada ketentuan penutup yaitu pada pasal 47 ayat (1) yang menyatakan: pelanggaran HAM yang berat yang terjadi sebelum berlakunya UU Pengadilan HAM tidak menutup kemungkinan penyelesaiannya dilakukan oleh Komisi Kebenaran dan Rekonsiliasi yang dibentuk dengan undang-undang.

Pembentukan komisi ini, menurut Jawahir Thontowi memiliki relevansi sebab proses pengadilan sebagai lembaga kedaulatan hukum suatu negara ternyata bukanlah satu-satunya cara umat manusia menyelesaikan konflik secara adil. Karena itu apa yang dikatakan Steve Smith terkait dengan sikap kompromi dalam suatu penyelesaian diplomatik berkesesuaian. "dunia yang saat ini kita jumpai adalah dunia dimana kedaulatan negara menjadi kurang relevan dan kurang mampu memecahkan masalah utama kemanusiaan dari pada peran nilai-nilai masyarakatnya" 13

Selain itu, memilih jalur penyelesaian diplomatis untuk menyelesaikan kasus pelanggaran berat HAM, bahwa untuk kasaskasus tertentu menjadi pilihan. Sebab, sistem hukum nasional dan internasional terkadang tidak dapat diterapkan. Sebab, selain tidak mampu mengakomodir perbedaan kepentingan kedua Negara, juga pertimbangan kemaslahatan bagi kepentingan nasional menjadi target utama. ${ }^{14}$

Dari pernyatan pasal tersebut dapat disimpulkan bahwa penyelesaian kasus pelanggaran HAM berat di Indonesia dilakukan oleh Pengadilan HAM, Pengadilan HAM Ad-hoc dan Komisi Kebenaran dan Rekonsiliasi. Diluar ketentuan mengenai penyelesaian perkara pelanggaran HAM berat, UU Pengadilan HAM melalui pasal 34 diatur tentang perlindungan korban dan saksi, sedangkan pemberian hak untuk mendapatkan kompensasi, restitusi dan rehabilitasi kepada korban pelanggaran HAM berat maupun kepada ahli warisnya diatur pada pasal 35 .

\section{UUPH dan Statuta Roma}

Menyoal instrumen hukum internasional sebagai salah satu basis sumber hukum nasional, sudah cukup lama menjadi perdebatan yang tidak kunjung selesai, terutama terkait dengan pengaruh instrumen hukum internasional tersebut dalam kerangka pembentukan hukum nasional. Hal tersebut terkait dengan prinsip kedaulatan negara atau "state souvereignty" yang merupakan prinsip umum hukum internasional. Prinsip ini telah menjadi perdebatan para ahli hukum internasional sejak lama yang kemudian dijelaskan melalui teori monisme dan

13. Jawahir Thontowi, dalam Penyelesaian HAM Indonesia-Timor Timur, diakses dari www.jawahirthontowi.wordpress.com, pada
tanggal 15 Desember 2014 14. Loc.cit. 
dualisme. Perkembangan kedua teori tersebut oleh setiap negara ditanggapi berbeda-beda sesuai dengan kepentingan nasionalnya. Ada negara yang mengutamakan teori monisme primat hukum nasional dan ada negara yang mengutamakan teori monisme primat hukum internasional. ${ }^{15}$

Menurut Romli Atmasasmita, berdasarkan Mukadimah UUD 1945 dan batang tubuhnya, ada penegasan bahwa NKRI merupakan Negara Kesatuan "territorial integrity" yang mengutamakan prinsip teritorialitas sebagai acuan utama. Prinsip kedaulatan dalam bentuk asli adalah menjaga keutuhan wilayah territorial dan mencegah terjadinya intervensi dari negara lain (dunia / kekuatan internasional), sedangkan "Montevideo Convention on The Rights and Dutiesnof States" tahun 1933 menegaskan bahwa, negara selaku subjek hukum internasional mensyaratkan 4 (empat) kualifikasi, yaitu: (a) memiliki penduduk tetap; (b) memiliki batas wilayah tertentu;(c) memiliki pemerintahan, dan (d) memiliki kapasitas dan kemampuan untuk mengadakan hubungan dengan negara lain. Singkatnya konvensi tersebut menentukan syarat negara untuk diakui sebagai subjek hukum internasional yang meliputi tiga syarat utama, yaitu memiliki pemerintahan, memiliki teritorial, memiliki penduduk tetap, dan kemampuan untuk melakukan hubungan internasional.

Pernyataan tersebut mengisyaratkan bahwa dalam tata kehidupan dunia dalam konteks kekinian (modern), menjadi keniscayaan hubungan antar bangsa dalam hampir semua aspek kehidupan, termasuk dalam penanggulangan kejahatan yang berhubungan dengan hak asasi manusia yang kemudian pada tataran internasional menghasilkan berbagai macam produk instrumen hukum internasional / konvensi internasional, walaupun dalam realitasnya akan menghasilkan beragam tanggapan atau sikap yang berbeda-beda diantara bangsabangsa di dunia, khususnya dalam mengadopsi instrumen internasional tersebut dalam hukum nasionalnya.

Terdapat beberapa variasi berkaitan dengan sikap yang dianut peradilan / hukum nasional berkenaan dengan pemberlakuan hukum internasional, antara lain: ${ }^{16}$

a. Di sebagian besar negara, kaidah hukum internasional diterapkan sebagai bagian dari hukum internal oleh pengadilanpengadilan nasional, tanpa perlu adanya tindakan khusus inkorporasi, dengan ketentuan bahwa tidak ada konflik dengan hukum nasional yang berlaku;

b. Sebagian kecil (minoritas) negara yang melaksanakan praktek dimana tanpa perlu ada tindakan khusus inkorporasi, pengadilan-pengadilan nasionalnya memberlakukan kaidah-kaidah hukum internasional lebih diutamakan dalam hal terjadi konflik dengan undangundang nasional;

c. Tidak terdapat praktek yang seragam mengenai pemberlakuan traktat di dalam lingkungan hukum nasional karena setiap negara memiliki kekhususan tersendiri.

Pendapat Starke seperti yang dikutip di atas, menunjukkan bahwa keberlakuan instrumen internasional dalam sistem hukum nasional sangat dipengaruhi oleh pertimbangan yang dimiliki oleh masingmasing negara dan tidak bisa juga dilepaskan dari konteks sosial budaya yang menjadi latar belakang argumentasi yang dikemukakan, apalagi kalau hal tersebut menyangkut persoalan yang berhubungan dengan hak asasi manusia, sebab sebagaimana dikemukakan Muladi, pandangan bangsa-bangsa terhadap HAM terbagi menjadi 4 (empat) yaitu: pandangan universal absolut, pandangan universal relatif, pandangan partikularistik absolut dan pandangan partikularistik relatif. ${ }^{17}$

Sebagai suatu bangsa, Indonesia tidak mungkin melepaskan diri dari bagian dalam komunitas dunia internasional, juga dalam hal upaya penanggulangan kejahatan. Hal ini terjadi sebagai konsekuensi dari semakin tipisnya batas-batas negara yang dipicu oleh kemajuan teknologi, tetapi juga terdapat fenomena baru munculnya kejahatankejahatan yang berdimensi internasional yang tidak mungkin bisa ditanggulangi tanpa adanya kerjasama internasional.

15. Romli Atmasasmita, Pengaruh Hukum Internasional terhadap Proses Legislasi, diakses dari www.parlemen.net, diakses pada tanggal 2 Desember 2014

16. J.G. Starke, Pengantar Hukum Internasional, Jakarta, Sinar Grafika, 1995, hlm. 112

17. Muladi, Hak Asasi Manusia, Politik dan Sistem Peradilan Pidana, Semarang, BP Undip, 1997, hal 2-3 
Oleh karenanya, tidak bisa dipungkiri bahwa karakteristik operasional hukum pidana materiil Indonesia mendatang antara lain bahwa hukum pidana mendatang harus dapat menyesuaikan diri dengan kecenderungan-kecenderungan universal yang tumbuh di dalam pergaulan masyarakat beradab, tetapi tidak harus mengikuti arus. ${ }^{18}$

Pernyataan tersebut relevan sebab dalam beberapa kali Konggres PBB tentang "Crime Prevention and The Treatment of Offenders" telah direkomendasikan beberapa jenis kejahatan yang memiliki dimensi internasional yang perlu mendapatkan perhatian serius oleh tiap-tiap negara di dunia, antara lain kejahatan corruption, organized crime, terrorism dan crimes againts humanity.

D e mikian halnya de ngan penyelenggaraan pengadilan HAM yang diatur dalam UUPH, sebagai produk hukum nasional, diakui tidak bisa dilepaskan dari keberadaan instrumen internasional, sebagaimana terlihat dalam penjelasan umumnya yang menyatakan bahwa UU Pengadilan HAM mengandung suatu misi mengemban tanggungjawab moral dan hukum dalam menjunjung tinggi dan melaksanakan Deklarasi Universal HAM yang ditetapkan PBB, demikian juga penjelasan pasal 7 yang menyatakan bahwa ketentuan mengenai kejahatan genosida dan kejahatan terhadap kemanusiaan yang merupakan pelanggaran HAM berat adalah sesuai dengan "Rome Statute of the International Criminal Court" (Statuta Roma) pasal 6 dan pasal 7".

Keterkaitan UUPH dengan Statuta Roma menjadi pembicaraan yang cukup penting mengingat Indonesia telah menyetujui ketentuan-ketentuan yang terdapat dalam statuta tersebut sebagai salah satu dokumen internasional, akan tetapi sampai sekarang belum melakukan ratifikasi terhadapnya, sehingga awal kelahiran UU Pengadilan HAM mendapatkan reaksi yang beragam.

Dari kelompok kritis yang sebagian besar berasal dari kalangan aktivis HAM memberikan reaksi yang cukup keras antara lain dengan meminta supaya Indonesia melakukan ratifikasi terhadap Statuta Roma, sebab mereka menilai bahwa sebagian besar materi yang diatur dalam UU Pengadilan HAM tidak sama persis dengan pengaturan yang telah disepakati dunia internasional dalam Statuta Roma sebagai sumber hukum penegakan terhadap pelanggaran HAM berat. Mereka menilai bahwa pasal-pasal yang terdapat dalam UU Pengadilan HAM masih banyak sekali ditemukan kelemahan.

Beberapa catatan yang melihat adanya kelemahan atau ketidaksesuaian materi pengaturan UUPH dengan Statuta Roma dikemukakan antara lain oleh Ifdhal Kasim. Menurutnya pengaturan mengenai hukum acara pengadilan HAM merupakan bagian terlemah, karena tidak melihat pengalamanpengalaman pengadilan internasional untuk Rwanda atau bekas Yugoslavia, sehingga bisa mengacu kepada pengadilan tersebut dalam menetapkan hukum acara bagi pengadilan hak asasi manusia. Yang terjadi justru mengacu dan mengandalkan KUHAP, yang masih banyak kelemahannya.

Tentang alat bukti dan cara bagaimana mendapatkannya dengan demikian aturannya mengacu kepada KUHAP. Itu artinya sangat tidak mungkin alat-alat bukti yang berupa rekaman video, kaset atau fotokopi dan pernyataan-pernyataan (statement) dipergunakan di dalam proses persidangan. Padahal dalam kasus persidangan Rwanda dan bekas-Yugoslavia, alat-alat bukti seperti itu dibenarkan. Termasuk mendengarkan kesaksian dari para saksi di hadapan televisi pengamat terbatas (closed circuit television). KUHAP masih sangat konvensional dalam mengatur tentang alat bukti dan pembuktian, karenanya sangat tidak memadai untuk diterapkan pada perkara-perkara yang diperiksa di pengadilan HAM yang memiliki kerumitan tersendiri. ${ }^{20}$

Demikian juga pembatasan waktu hanya dalam jangka 180 hari bagi pemeriksaan di pengadilan jelas sangat kaku. Begitu juga jangka waktu yang ditetapkan bagi proses penyelidikan dan penyidikan, yang sangat terbatas. Pembatasan waktu ini jelas perlu agar ada ancangan waktu, tetapi tidak bisa ditetapkan sebagai suatu kewajiban. Perkaraperkara pelanggaran hak asasi manusia bukan

18. Muladi, Proyeksi Hukum Pidana Materiil, op.cit, hlm. 18

Barda Nawawi Arief, 2001, Masalah Penegakan Hukum dan Kebijakan Penanggulangan Kejahatan, Bandung, Citra Aditya 19. Bhakti, hlm. 81

20. Ifdhal Kasim, op.cit 
perkara yang sederhana, tetapi seringkali merupakan perkara yang bersifat rumit dan peka.

Ketidaksesuaian juga terjadi dalam penetapan asaa-asasnya, antara lain mengenai pemberlakuan secara surut UU Pengadilan HAM karena dinilai bertentangan dengan asas legalitas yang dijamin oleh konstitusi negara.

Berbagai kritik yang ditujukan pada substansi materi pengaturan dalam UUPH inilah yang melahirkan adanya tuntutan kepada pemerintah untuk segera melakukan ratifikasi Statuta Roma, sebab sebagaimana ditulis dalam briefing paper oleh Koalisi Masyarakat Sipil untuk Mahkamah Pidana Internasional, ratifikasi Statuta Roma memiliki urgensi dan keuntungan bagi Indonesia yaitu: ${ }^{21}$

1) Menunjukkan pada dunia keteguhan Indonesia dalam penegakan HAM dan penguatan demokrasi. Menunjukkan komitmen untuk memerangi kejahatan serius dan memutuskan rantai impunitas;

2) Ratifikasi Statuta Roma akan menjadikan Indonesia sejajar dengan 104 negara-negara di dunia yang sudah lebih dulu mengikatkan dirinya pada tatanan keadilan internasional ini. Dengan ini pula, Indonesia sebagai negara demokrasi terbesar ketiga di dunia dan negara terbesar di Asia Tenggara menjadi contoh upaya perlindungan HAM di kawasan Asia dan dunia;

3) Indonesia dapat menggunakan mekanisme ICC sesuai dengan semangat Pemerintah Indonesia seperti termaktub dalam Pembukaan UUD 1945 yaitu melindungi segenap bangsa Indonesia dan seluruh tumpah darah Indonesia dan majukan perdamaian dunia;

4) Memberikan Jaminan dan perlindungan bagi warga negara Indonesia. Dengan meratifikasi Statuta Roma, pemenuhan mandat ini semakin mungkin diwujudkan karena Statuta Roma memberikan jaminan bagi buruh migran dan anggota TNI/Polri dalam Pasukan
Perdamaian PBB.

Realitas dukungan agar pemerintah segera melakukuan ratifikasi Statuta Roma antara lain ditunjukkan oleh DPR RI sejak tahun 2007, telah memberikan dukungan dan komitmen untuk meratifikasi Statuta Roma, antara lain menegaskan komitmen untuk meratifikasi Statuta Roma sebelum habisnya masa bakti DPR 2004 - 2009. Demikian juga dukungan masyarakat sipil. dalam berbagai forum yang digagas Koalisi Masyarakat Sipil untuk Ratifikasi Statuta Roma, berbagai elemen masyarakat menyatakan dukungan dan bergabung dalam koalisi. Hingga saat ini sudah lebih dari 100 organisasi dan akademisi yang bergabung dalam koalisi mendukung ratifikasi Statuta Roma. Sementara dari pihak pemerintah (c.q Depkumham RI) sedang mengupayakan Naskah Akademis dan draft RUU. Dorongan untuk mempercepat proses sangat diperlukan agar ratifikasi Statuta Roma untuk ICC dapat terwujud sebelum Pemilihan Presiden 2009.

\section{Urgensi Ratifikasi}

Terkait dengan persoalan ratifikasi ini, terdapat 2 (dua) model atau cara mengikatkan diri suatu sistem hukum negara ke dalam suatu perjanjian internasional yang berbeda-beda sesuai dengan sistem hỉukum yang dianut suatu negara "Civil Law system" atau "Common Law System".

Pada sistem hukum "Civil Law", penandatanganan suatu perjanjian (signing) tidak serta merta menjadi sumber hukum nasional sebelum dilakukan ratifikasi oleh parlemen (non-self implementing legislation). Sebaliknya di dalam sistem hukum "Common Law", penandatanganan suatu perjanjian serta merta merupakan sumber hukum nasional (self-implementing legislation).

Bagi Indonesia yang masih menganut sistem hukum "Civil Law", pemberlakuan perjanjian internasional ke dalam sistem hukum nasional masih memerlukan proses ratifikasi oleh Dewan Perwakilan Rakyat RI. Hal ini sesuai dengan ketentuan dalam UUD 1945 tentang sahnya suatu perjanjian

21. Diakses dari www.eslam.or.id sebagaimana ditulis oleh Simon, dalam Briefing Paper "sekaranglah saatnya Indonesia meratifikasi Statuta Roma tentang ICC"

22. Loc.cit.

23. Romli Atmasasmita, Pengaruh Hukum Internasional terhadap Proses Legislasi, op.cit, dalam www.parlement.net, diakses tanggal 3 Desember 2014 
internasional dan merujuk kepada Undangundang RI Nomor 37 tahun 1999 tentang Hubungan Luar Negeri dan Undang-undang Nomor 24 tahun 2000 tentang Perjanjian Internasional.

Peratifikasian suatu perjanjian internasional yang telah ditandatangani pemerintah Indonesia mutatis mutandis merupakan hukum nasional (hukum positif) sebagai dasar penerapannya di dalam praktik. Namun demikian dalam proses legislasi di Indonesia, peratifikasian tersebut diwujudkan dalam suatu "Undang-undang Pengesahan". Implementasi undang-undang ratifikasi (pengesahan) tersebut masih harus melalui suatu proses harmonisasi dengan undangundang lama dalam hal objek perjanjian internasional telah dimuat sebagian atau seluruhnya di dalam ketentuan peraturan perundang-undangan yang berlaku. ${ }^{24}$

Terkait dengan peratifikasian instrumen internasional ke dalam sistem hukum Indonesia, menarik sebuah kajian akademik yang dilakukan oleh Hikmahanto Juwana. Menurutnya, perjanjian internasional bukanlah sesuatu yang netral dan bebas nilai, terlebih perjanjian internasional yang bersifat multilateral. Perjanjian seperti ini sering dianggap sebagai international norm creating atau pembentukan norma internasional yang sangat bergantung pada siapa yang mengawali mengambil inisiatif. ${ }^{25}$

Akibatnya, mengingat bahwa perjanjian internasional lebih banyak dilahirkan oleh negara maju di belahan Eropa (Barat), maka sering ditemukan instrumen internasional, meskipun diikuti oleh banyak negara, sulit diimplementasikan di negara-negara berkembang karena tidak memperhatikan kondisi sosial budaya negara-negara tersebut, bahkan sering juga terjadi perjanjian internasional yang bersifat multilateral, dijadikan / dimanfaatkan sebagai instrumen politik (international treaty as political instrument) untuk mengintervensi keadulatan hukum, politik, ekonomi dan budaya suatu negara. ${ }^{26}$

Oleh karenanya, sebelum melakukan ratifikasi suatu perjanjian internasional, perlu dipertimbangkan beberapa hal penting, yaitu: ${ }^{27}$

a. Departemen atau instansi teknis yang menginisiatifkan untuk ikut serta dalam suatu perjanjian internasional perlu mengetahui secara akurat kemampuan pemerintah dan DPR dalam menterjemahkan ketentuan dan kewajiban perjanjian internasional ke dalam hukum nasional;

b. Kesiapan pemerintah untuk dipantau atau memberi laporan mengenai progres pelaksanaan instrumen internasional yang telah diratifikasi;

c. Kapasitas aparat penegak hukum sebagai konsekunsi dari komitmennya; dan

d. Perlunya dilihat negara-negara yang telah ikut serta dalam kerangka kerjasama antar negara demi mengambil manfaatnya.

Dari pendapat tersebut, dapat disimpulkan bahwa sebelum sampai pada proses ratifikasi suatu perjanjian internasional, terdapat 3 (tiga) hal yang terlebih dahulu perlu dipertimbangkan yaitu proses transformasi dan harmonisasi instrumen hukum internasional dalam sistem hukum nasional, kesiapan pemerintah dan aparatur penegak hukum dalam menjalankan instrumen internasional sebagai konsekuensi peratifikasian dan asas kemanfaatan peratifikasiaan dalam konteks kepentingan nasional.

Proses transformasi dan harmonisasi ini menjadi sangat urgen dan krusial, sebab sekiranya Statuta Roma akan diacu sebagai sumber bahan utama bagi model penyelesaian HAM berat di Indonesia, maka UU Pengadilan HAM yang sekarang ini ada, perlu menyesuaikan diri dengan instrumen hukum internasional tersebut pada satu sisi, dan pada sisi lain harus pula memperhatikan harmonisasi / sinkronisasi vertikal dan horisontal sistem hukum nasional, sehingga tidak terjadi tumpang tindih (overlapping) dan saling benturan dalam hal pengaturannya.

Secara umum masalah bisa muncul terkait dengan penerjemahan ketentuan pada

\footnotetext{
24. Loc.cit

Hikmahanto Juwana, Hukum Internasional dalam Perspektif Indonesia sebagai Negara Berkembang; Jakarta: Yarsif 25. Watampone, 2010, hlm. 69

26. Loc.cit

27. Ibid, hlm. $81-83$
} 
Statuta Roma (dalam bahasa Inggris) ke dalam bahasa Indonesia, kadang-kadang menimbulkan multi tafsir dari kalangan yang terlibat dalam perumusan undang-undang, demikian juga mengenai asas non-retroaktif (tidak berlaku surut) maupun ancaman pidana mati yang tidak dianut oleh ketentuan yang diatur dalam Statuta Roma.

Penting juga hal-hal yang terkait dengan proses konsistensi penegakan hukumnya dan komitmen pemerintah, sebab kasus-kasus yang berhubungan dengan pelanggaran HAM berat biasanya terdapat kecenderungan dan terkait dengan kekuasaan dalam rezim tertentu, oleh karenanya sering terjadi pertimbangan-pertimbangan non-yuridis (misalnya pertimbangan politis) sangat berpengaruh terhadap bekerjanya sistem peradilan pidana dalam penanganan HAM berat di Indonesia. Demikian juga halnya terkait dengan pemahaman dan kemampuan aparatur penegak hukum mengenai unsurunsur yang terdapat pada delik pelanggaran HAM berat.

Sedangkan dari sisi kemanfaatan peratifikasian, perlu dipikirkan secara mendalam apakah instrumen internasional tersebut benar-benar berpihak pada kepentingan hukum Indonesia, baik secara langsung maupun tidak langsung. ${ }^{28}$ Relevan dengan pendapat tersebut, Jawahir Thontowi menyatakan bahwa pertimbangan kemaslahatan bagi kepentingan nasional seharusnya menjadi target utama, terkait dengan penyelesaian konflik pelanggaran HAM sebab instrumen internasional terkadang tidak dapat diterapkan, sehingga pendekatan penyelesaian melalui jalur diplomasi atau perundingan dapat menjadi alternatiflain..$^{29}$

Asas kemanfaatan ini juga perlu melihat negara-negara mana saja yang telah melakukan ratifikasi Statuta Roma, karena hal ini menjadi sangat penting apabila terjadi konflik antar negara terkait dengan kepentingan hukum yang cenderung berbeda pada tiap-tiap negara di dunia. ${ }^{30}$

\section{Simpulan}

Dari kajian sebagaimana telah diuraikan di atas, dapat diambil simpulan sebagai berikut:

1. UU nomor: 26 tahun 2000 tentang Pengadilan HAM merupakan salah satu produk hukum yang berbasis instrumen hukum internasional yaitu Statuta Roma, yang memiliki yurisdiksi menangani perkara tindak pidana pelanggaran HAM berat. Sekalipun UU ini berkiblat pada Statuta Roma, tetapi subtansinya tidak persis sama, sehingga sejak awal kelahirannya telah melahirkan kritik yang cukup tajam.

2. Sampai saat ini, Indonesia belum melakukan ratifikasi terhadap Statuta Roma sehingga disarankan oleh banyak kalangan terutama dari para aktivis HAM, selayaknya Indonesia segera melakukan ratifikasi instrumen hukum internasional tersebut.

3. Terdapat juga pandangan yang menyatakan bahwa perlu dilakukan pertimbangan yang matang dan mendalam sebelum Indonesia melakukan ratifikasi terhadap instrumen hukum internasional tersebut, khususnya dalam perspektif harmonisasi hukum nasional, kesiapan pemerintah dan pertimbangan kemanfaatannya.

Berdasarkan simpulan di atas, maka dapat disampaikan saran bahwa Terkait dengan pandangan yang agak berbeda mengenai urgensi ratifikasi Statuta Roma bagi Indonesia, pemerintah perlu segera mengambil langkah strategis untuk melakukan kajian mendalam terkait dengan hal tersebut yang melibatkan semua kalangan dengan orientasi kepentingan nasional Indonesia. Peratifikasian Statuta Roma harus juga dibarengi dengan upaya konkrit untuk menyesuaikan norma-norma instrumen hukum internasional tersebut ke dalam sistem hukum nasional, melakukan harmonisasi dalam konteks sistem hukum nasional (secara vertikal dan horisontal), kesiapan aparatur penegakan hukumnya, ketersediaan sarana prasarana yang mendukung penegakan hukum (termasuk institusi pendukungnya), political will pemerintah serta upaya

28. Hikmahanto Juwana, op.cit, hlm. 74.

29. Jawahir Thontowi, Op.cit. ik.

30. ibid, hlm. 84. 
menjunjung tinggi dan pemajuan penghormatan terhadap HAM dalam seluruh aspek kehidupan oleh semua pihak.

\section{DAFTAR PUSTAKA}

Arief, Barda Nawawi, 2001, Masalah Penegakan Hukum dan Kebijakan Penanggulangan Kejahatan, Bandung: Citra Aditya Bhakti

Atmasasmita, Romli, Pengaruh Hukum Internasional terhadap Proses Legislasi, dalam www.parlemen.net

Juwana, Hikmahanto, 2010 , Hukum Internasional dalam Perspektif Indonesia sebagai Negara Berkembang; Jakarta: Yarsif Watampone

Karnasudirdja, Eddy Djunaedi, 2003, Dari Pengadilan Internasional Nuremberg ke Pengadilan Hak Asasi Manusia Indonesia, Jakarta: PT. Tatanusa

Kasim, Ifdhal, UU Pengadilan HAM Sebuah Tinjauan, Jakarta: ELSAM, dalam www.eslam.or.id

Muladi, Hak Asasi Manusia, 1977, Politik dan Sistem Peradilan Pidana, Semarang: BP Undip

Muladi, 1990, Proyeksi Hukum Pidana Materiil Indonesia di Masa Datang, Pidato Pengukuhan Penerimaan Jabatan Guru Besar Ilmu Hukum Pidana di Fakultas Hukum UNDIP Semarang; 24 Pebruari 1990

Thontowi, Jawahir, Penyelesaian HAM Indonesia - Timor Timur, dalam www.jawahirthontowi.wordpress.com

Tumpa, Harifin A, 2006, Yurisdiksi Peradilan Pidana Indonesia Terhadap Pelanggaran HAM Berat dalam Rangka Penerapan Statuta Roma di Indonesia, Jakarta: majalah Varia Peradilan edisi tahun ke-XXI no. 252 November 2006

Silitonga, Inggrid, Penegakan Keadilan atas
Pelanggaran Berat HAM menurut UU nomor 26 tahun 2000, Skenario Indonesia versus Standard Internasional, dalam www.eslam.or.id Suarda, I Gede Widhiana, 2012, Hukum Pidana Internasional Sebuah Pengantar, Bandung: Citra Aditya Bhakti

Starke, J.G, 1995, Pengantar Hukum Internasional, Jakarta, Sinar Grafika 